\title{
Use of The Electromagnetic Field of Low Frequencies in the Production of Sausages
}

\author{
Anton Nesterenko, Viktor Goushchin, Andrey Koshchaev, Maksim Rebezov, Mars Khayrullin
}

\begin{abstract}
This article presents the results of the research influence of electromagnetic field on the microflora of fresh sausage. Agents, by using a field had a frequency range from 10 to $110 \mathrm{~Hz}$, and the duration of exposure ranged from 15 to $60 \mathrm{~min}$ After exposure frequency of $10 \mathrm{~Hz}$ for 30 minutes, micrographic study showed a partial destruction of cellular structures, reduced ability to bind water and reduce microbiological contamination of meat. It was found that the treatment of starter cultures "ALMI-2" with a frequency of $45 \mathrm{~Hz}$ for 60 minutes stimulates their growth. Low-frequency starter cultures, processed by electromagnetic method, reduce the $\mathrm{pH}$, moisture-binding and water-retaining ability of ground meat and increase its stickiness.
\end{abstract}

Keywords : electromagnetic treatment, fresh sausage meat, starter cultures, biomodification, test ground meat.

\section{INTRODUCTION}

The summer sausages production technology is one of the most complicated, time-consuming and labor-intensive. A number of biochemical and physical-chemical processes take place during the ageing of this kind of food products. They contribute to the formation of specific taste, smell and color of ready-to-use sausages (Nesterenko and Kenijz 2014; Dumin et al. 2002).

The foreign and Russian sources show that currently the technology of summer sausages production may use modern technologies that speed up the ageing. Usually, starter cultures (sometimes in combination with glucono-delta-lactone) are used for ageing intensification (Nesterenko 2014; Hu et al. 2014).

The use of starter cultures together with

Revised Manuscript Received on December 30, 2019.

* Correspondence Author

Anton Nesterenko*, Kuban State Agrarian University named after I.T. Trubilin, Krasnodar, Russia. Email: nesterenko-aa@mail.ru

Viktor Goushchin, All-Russian Scientific Research Institute of Poultry Processing Industry - branch of the Federal State Budget Scientific Institution Federal Scientific Center "All-Russian Research and Technological Poultry Institute" of the Russian Academy of Sciences, Solnechnogorsk district, Moscow region, Russia. Email: nesterenko-aa@mail.ru

Andrey Koshchaev, Kuban State Agrarian University named after I.T. Trubilin, Krasnodar, Russia. Email: nesterenko-aa@mail.ru

Maksim Rebezov, K.G. Razumovsky Moscow State University of technologies and Management (the First Cossack University)», Moscow, Russia; Ural State Agrarian University, Yekaterinburg, Russia; V.M. Gorbatov Federal Research Center for Food Systems of the Russian Academy of Sciences, Moscow, Russia.. Email: nesterenko-aa@mail.ru

Mars Khayrullin, K.G. Razumovsky Moscow State University of technologies and Management (the First Cossack University)», Moscow, Russia. Email: nesterenko-aa@mail.ru

(C) The Authors. Published by Blue Eyes Intelligence Engineering and Sciences Publication (BEIESP). This is an open access article under the CC BY-NC-ND license (http://creativecommons.org/licenses/by-nc-nd/4.0/) glucono-delta-lactone results in intensification of passive indicators of ageing, such as sharp decline of the $\mathrm{pH}$ of the ground meat, dense structure formation, and color change.

In order to accelerate the ageing and drying of summer sausages, the glucono-delta-lactone (GDL) additives are used. GDL is an anhydrite of gluconic acid that turns into gluconic acid again in contact with water. At the same time, the $\mathrm{pH}$ reduces; the acid formation speeds up under heating. GDL is very significant in dry sausages production due to the following features:

- rapid densification of the texture due to the sharp decrease of $\mathrm{pH}$. This also implies that fresh sausage meat with GDL should be bound into the casings immediately after mixing;

- accelerated coloration by nitrite reduction to nitrogen oxide (caused by the acid);

-inhibition of the bacteria growth sensitive to the $\mathrm{pH}$ reduction. The safety of critical products may be increased by using GDL. However, the inhibitory effect of GDL on undesired bacteria is not as strong as the effect of various food acids. As part of the overall safety concept and together with other factors, the bacteriostatic effect of GDP may appear sufficient (Timoshenko et al. 2016; Shipulin et al. 2010).

However, GDL may also cause problems in dry sausages production:

- non-standardbluish red color caused by excessively rapid and intensive acid production. This problem results from the GDL overdosing;

- in case of GDL overdosing, one may taste bitter and sour components that ruin the sensory standard;

- GDL does not inhibit the peroxide-forming bacteria. The peroxide decomposes fats and destroys the coloration. For this reason, GDL should be used in combination with catalase-positive starter cultures only;

- GDL may decomposeunder the influence of heterofermentative lactobacilli, resulting in an unpleasant sourish off-flavor. This problem may be avoided by using homofermentative lactobacilli in the form of the starter culture(s)(Timoshenko et al. 2016).

The use of starter cultures promotes the formation of flavor and color characteristics of the ready-to-use products (Starostina et al. 1997a). One of the significant characteristics of starter cultures is their ability to produce lactic acid from carbohydrates, thus reducing the $\mathrm{pH}$ level in dry sausages. Carbohydrates are found in meat in the form of muscle glycogen and are added into ground meat during the production of dry sausages. 


\section{Use of The Electromagnetic Field of Low Frequencies in the Production of Sausages}

Dextrose, lactose, sucrose and maltodextrin are commonly used (Radchenko et al. 2016;Starostina et al. 1997b).

The use of various sugars affects the rate of development of useful microflora, which speeds up the technological process of the summer sausages production. Sugars perform a variety of functions in dry sausages: they serve as "food" for fermentation, directly affect the taste of the product, allow the product to reach a certain degree of density (or spreadability), and are a cheaper filler if compared to meat. However, the use of sugar as a filler is advantageous only until it leads to excessive oxidation and to further significant weight loss (Timoshenko 2016; Tsinpaev2008).

The composition and volume of added sugars have a significant influence on the sensory characteristics (acidity, density, flavor development), as well as on the ageing process of dry sausages (Timoshenko 2016).

Changing the technology may affect the quality of a ready product, since the flavor, taste and structure of sausages may significantly change (Nesterenko and Kenijz 2014; Dumin et al. 2002). Thus, the technological process intensification should be accompanied by maintaining the high consumer properties of the ready product. Both Russian and foreign researchers work in this field.

Analysis of literature sources indicates that today using the low frequency electromagnetic field (LF EMF) is one of the promising areas of intensifying the technological process of the summer sausages production. However, the use of LF EMF requires the study of the optimal frequency, the human safety issues, the industrial use of LF EMF, and the effect of LF EMF on starter cultures and fresh sausage meat (Baryshev 2008).

In this regard, our research objective is to study the LF EMF effect on fresh sausage meat and starter cultures, and to apply the data obtained in improving the technology of summer sausages production.

To develop the improved summer sausages productiontechnology, the following tasks were set:

- to intensify the technological process by speeding up the ageing of sausages;

- to inhibit undesirable microflora and to accelerate the starter cultures growth;

- to obtain a high quality product;

- to achieve applicability of the proposed solutions at any enterprise without considerable preparation.

\section{MATERIALS AND METHODS}

According to the tasks set, the authors selected the research objects and methods and developed a pattern for experimental set-up. To study the possible LF EMF effect on the starter cultures microflora and the fresh sausage meat structure, the authors took the following as research objects: refrigerated beef kept at a temperature of $0 \mathrm{oC}$ during 24 hours, refrigerated pork kept at a temperature of $0 \mathrm{oC}$ during 18 hours and the starter cultures "Al'mi 2" by Al'mi.

Experimental studies were carried out at Kuban State Agrarian University named after I.T. Trubilin (KubSAU): laboratories of the Department of Technology of Storage and Processing of Livestock Products; the Department of Biotechnology, Biochemistry and Biophysics; the Department of Electrical Energy Application; at "ARGUS" test center. The experiments used the following equipment:
M 2015 multi-range permanent-magnet ammeter, M 2004 voltmeter, CO-I446 single-phase meter. All devices were used to measure the power of direct current pulsations up to $150 \mathrm{~Hz}$. Magnetic field force was measured with "Impul's" device by Soeks. The indicators of the pointer devices were duplicated by an electronic double-channel oscilloscope ASK 2023 (Aktakom) and a four-channel digital memory oscilloscope TDS2014 (Tektronix). The pH was measured with $\mathrm{pH}-340$ potentiometer according to GOST R 51478-99 (2005).

The water-binding capacity (WBC) of raw material was determined with Grau-Hamm method (Antipova et al. 2001).

The number of mesophilic aerobes and facultative anaerobes was determined according to GOST 10444.15-94 (1994).

The mass change in raw material was measured by weighing on scales and calculating the percentage to the mass of original raw material. The moisture content was measured according to GOST 9793-74 (1990) by drying a batch until permanent weight at a temperature of $105{ }^{\circ} \mathrm{C}$. The water-retaining capacity (WRC) of the ground meat was measured as a difference between the moisture content and the amount of moisture withdrawn during the heating (Antipova et al. 2001). The stickiness was measured with the method by Sokolov-Bol'shakov (Antipova et al. 2001). The fractional composition of protein was determined by their solubility (Antipova et al. 2001). The meat was kept in 10\% neutral formaldehyde solution for 24 hours for histological examination. Then it was rinsed in cold water for 12 hours and covered with gelatin according to standard methodology. The material was cut with microtome thermostatic cooler MIKROM-HM 525 (Germany) at a temperature of $\cdot 20^{\circ} \mathrm{C}$, obtaining 10-15 micron thick slices. The slices of sausage were obtained at a temperature of the thermostatic cooler chamber of $\cdot 28^{\circ} \mathrm{C}$ (Khvylya 2002; Khvylya and Pchelkina 2007, 2013).

The slices were colored with Ehrlich's hematoxylin and finished with $1 \%$ freshaqueous alcoholic eosin, put under cover slips in glycerine-gelatin, which was previously melted on water bath (Khvylya 2002; Khvylya and Pchelkina 2007, 2013).

The microstructure examination of histological specimens and their photographing with digital photography equipment was carried out with a light microscope AXIOIMIGER.A1 (Carl Zeiss, Germany) with the attached AXIOVISION image analysis system using the corresponding morphological software with lens magnification from x2 to x63 (Khvylya 2002; Khvylya and Pchelkina 2007, 2013). The mathematic data processing was carried out with STATISTICA software in the following modules: descriptive statistics, correlation analysis and design of experiments. The method of quantitative determination of lactic acid with 2-oxydiphenyl (Antipova 2001) is based on measuring the coloration intensity of the compound formed during the reaction of acetaldehyde with n-oxidodiphenyl in the presence of sulfuric acid.

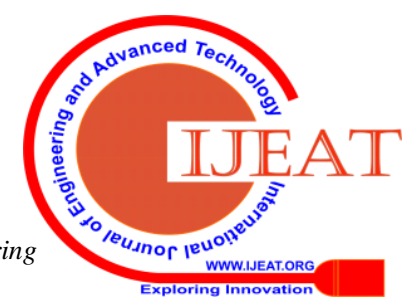


Proteins were removed by settling with trichloroacetic acid, and carbohydrates by settling with lime hydrate in the presence of cupric sulfate. Acetaldehyde formed from lactic acid by heating with sulfuric acid gives a color reaction with 2-oxydiphenyl (violet coloration).

Acetaldehyde is formed by heating lactic acid with mineral acids. Its interaction with two molecules of n-oxydiphenyl forms dioxydiphenylethane, which in the presence of $\mathrm{H}_{2} \mathrm{SO}_{4}$ is oxidized to a purple product with a maximum absorption at $574 \mathrm{~nm}$. This method allows determining lactic acid in amounts from 0.03 to $0.2 \mu \mathrm{mol}$ in a sample (Antipova 2001).

The organoleptic assessment of summer sausages was carried out with a scale from one to five:

- the appearance, color and the state of surface of the product in total were determined visually by examining the product. The color, pattern on the cut, structure of the ground meat and distribution of the ingredients in the ground meat were determined visually on the cross sections of a sausage stick;

- the flavor and taste of a ready product were determined by tasting. Simultaneously, the tasting revealed the strength of spices and smoking flavor and the possible presence of extraneous smells;

- in the evaluation of the texture, the density and elasticity of the sticks were taken into account.

The biological assessment of the summer sausages was carried out by traditional experimental methods on growing laboratory male rats during 28 days (Antipova 2001).

The weight gain was measured by individual weighing of animals 2 times a week on laboratory electronic scales.

The integrated index of chronic intoxication (IICI) was calculated by dividing the weight of an animal's organ by its body weight (Antipova 2001).

The laboratory rats were killed by single-stage decapitation.

The red blood count in rats' blood was determined under the microscope by counting in Goryaev chamber. The amount of hemoglobin was determined with Sali hemoglobinometer, the erythrocyte sedimentation rate (ESR) - in Panchenkov's capillary, the number of leukocytes - by counting in Goryaev chamber.

The diets for growing rats were formed in accordance with the norms of laboratory rats'demand in nutrients, as shown in Table 1 (GOST R 50258 - 92 1993).

Table - I: Diets for growing rats

\begin{tabular}{|l|c|c|}
\hline \multicolumn{1}{|c|}{ Title } & Control & Experiment \\
\hline Durum wheat & 23.4 & 33.4 \\
\hline Yellow corn & 35 & 1.5 \\
\hline Sausage & - & 50 \\
\hline Soybean cake & 8 & - \\
\hline Fish flour & 12 & - \\
\hline Dry milk & 6 & - \\
\hline Vegetable oil & 12 & - \\
\hline Lime phosphate & 2 & 2 \\
\hline Lysine monohydrochloride & 0.5 & 0.5 \\
\hline Methionine & 0.1 & 0.1 \\
\hline Premix & 1.0 & 1 \\
\hline TOTAL & 100 & 100 \\
\hline \multicolumn{2}{|c|}{$\mathbf{1 ~ k g ~ o f ~ f o d d e r ~ c o n t a i n s : ~}$} & \\
\hline Metabolic energy, megajoule & 13.0 & 13.0 \\
\hline Crude protein, \% & 19.6 & 19.5 \\
\hline Crude fat, \% & 15.8 & 15.9 \\
\hline Crude fiber, \% & 1.9 & 1.8 \\
\hline Calcium, \% & 1.1 & 1.0 \\
\hline
\end{tabular}

Retrieval Number: B4013129219/2019@BEIESP

DOI: 10.35940/ijeat.B4013.129219

Journal Website: www.ijeat.org

\begin{tabular}{|l|c|c|}
\hline Phosphorus, \% & 0.77 & 0.7 \\
\hline Lysine, \% & 1.5 & 1.44 \\
\hline Methionine+cystine & 0.7 & 0.7 \\
\hline
\end{tabular}

Biochemical blood tests of experimental rats were conducted in the laboratory of Krasnodar Scientific Research Veterinary Institute of the Russian Academy of Agricultural Sciences,with biochemical analyzer Vitalab Flexor Junior (Netherlands) using reference and regulatory documentation(Antonov 2001). Biochemical studies consisted in determining the total protein (colorimetric), protein fractions (nephelometric), calcium, phosphorus, iron, cholesterol, triglycerides, transaminase activity, and alkaline phosphatase in the blood serum using the Elitech Clinical Sestem kits.

The cutting resistivity (Borisenko et al. 2002) was determined by measuring the force necessary to break a sample by slicing in a constant volume chamber.

\section{RESULTS AND DISCUSSION}

Literary sources (Oboturova et al. 2012) show that LF EMF may cause resonance oscillations in a biological cell and destroy its structure, while the low-level oscillations may harmonize its functioning.

In cooperation with the colleagues from the Department of Electric Energy Application of Kuban State Agrarian University named after I.T. Trubilin, we developed a device for processing meat and starter cultures with LF EMF (Fig. 1). The device consists of an impulse generator and a control circuit to control the VD10 thyristor. The impulse generator consists of a source of low frequency electromagnetic oscillation and an emitter of electromagnetic impulses in the form of a solenoid. The source of radiation is a generator of unidirectional triangular impulses capable of generating frequencies in the range of $10-200 \mathrm{~Hz}$ (Nesterenko et al. 2017b).

1

2

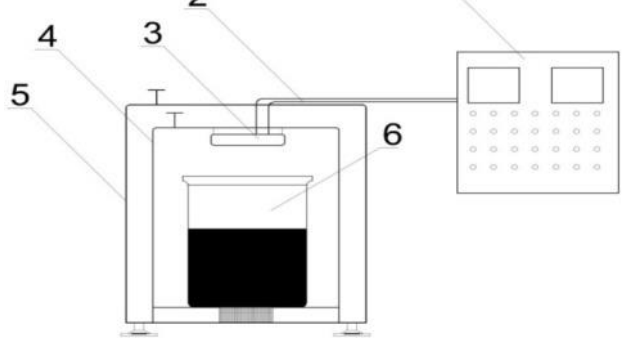

Fig. 1. Diagram of an electromagnetic device with a shielded contour: 1 - control unit; 2 - wire; 3 - coil; 4 - 1st protective contour; 5 - 2nd protective ferromagnet contour; 6 - processed sample

To study of LF EMF effect on the development of mesophilic aerobes and facultative anaerobes, we used refrigerated beef and pork. Raw meat samples were placed in a shielded chamber with a built-in MF emitter. Meat was exposed to triangular waveform in the ranges from 10 to 110 $\mathrm{Hz}$ for 15, 30, 45 and 60 minutes.
Published By:

Blue Eyes Intelligence Engineering \& Sciences Publication 
The research showed that the maximum peak of microflora development was achieved when LF EMF treatment was performed at a frequency of $45 \mathrm{~Hz}$ and lasted for 60 minutes (total viable count, CFU/g, in refrigerated beef $-8,1 \cdot 10^{7}$, in refrigerated pork $-6,8 \cdot 10^{7}$ )

(Fig. 2 and 3). Further increase in frequency resulted in significant inhibition of microflora development, the peak of which was at the frequency of $100 \mathrm{~Hz}$ with a duration of 60 min (total viable count, CFU/g, in refrigerated beef $-2,8 \bullet 10^{2}$, in refrigerated pork $-2,9 \cdot 10^{2}$ ) (Fig. 4 and 5).

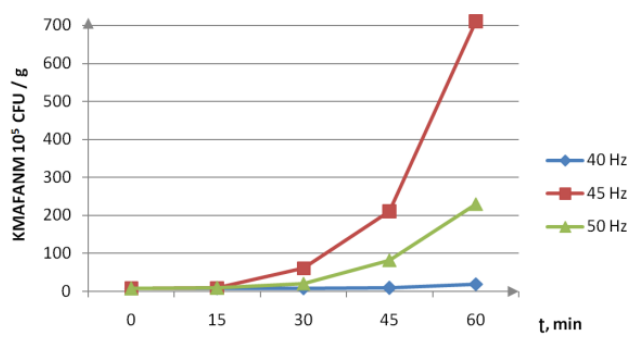

Fig. 2. Dynamics of total viable count in beef exposed to the frequency of 40-50 Hz depending on the LF EMF processing duration

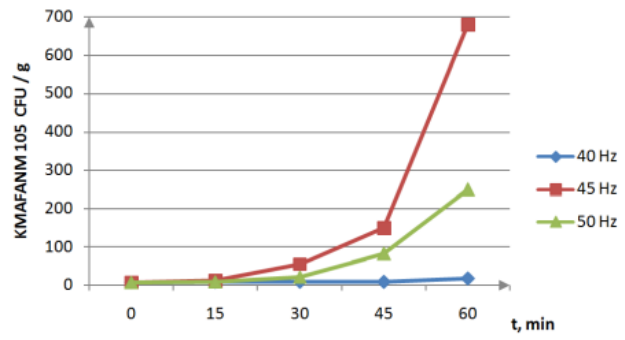

Fig. 3. Dynamics of total viable count of pork exposed to the frequency of 40-50 $\mathrm{Hz}$ depending on the LF EMF processing duration

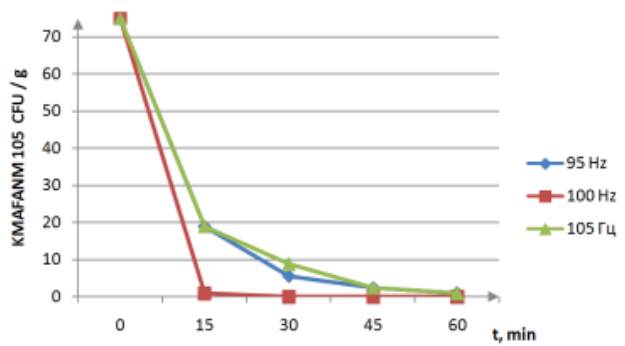

Fig. 5. Dynamics of total viable count of pork exposed to the frequency of 95-105 Hz depending on the LF EMF processing duration

The analysis of the results obtained after the processing of beef and pork at a frequency of $100 \mathrm{~Hz}$ shows that the differences in the indices between the processing durationranging from $30 \mathrm{~min}$ (total viable count, CFU/g, of refrigerated beef $-3,2 \cdot 10^{2}$, in refrigerated pork $-3,1 \cdot 10^{2}$ ) to $60 \mathrm{~min}$ (total viable count, CFU/g, in refrigerated beef $2,8 \cdot 10^{2}$, in refrigerated pork $-2,9 \cdot 10^{2}$ ), are not significant. Based on the data obtained, it was proposed to process fresh sausage meat with a frequency of $100 \mathrm{~Hz}$ during 30 minutes to intensify the growth of starter cultures, and to activate them at a frequency of $45 \mathrm{~Hz}$ during 60 minutes.

It is known (Koshchaev et al. 2016) that electromagnetic waves influence, first of all, on the membranes that limit various intracellular components. The individual structural elements of a cell have a liquid crystal structure. Therefore, anisotropy of the magnetic properties is typical for them. The obtained results show that the liquid crystals of such elements are guided by the magnetic field, being responsible for membrane permeability, which, in turn, regulates the biochemical processes occurring inside the cell (Koshchaev et al. 2016).

The research of the spectra of photons reflected from the treated product shows that the decontamination effect reaches its maximum at a waveform frequency of $100 \mathrm{~Hz}$. Taking into account that the resonance occurs when the oscillations amplitudes coincide, it is possible in case of a multiple ratio of the natural frequencies of the electrons oscillations and the frequencies of the external action, therefore the action frequency should be a whole number. The color of the reflected signal is blue, which means that the wavelengths of the emitted photons are whole numbers and vary in the range of $6.0 \cdot 10^{14} \cdot 7.0 \cdot 10^{14} \mathrm{~Hz}$. Thus, the resonance of the external LF EMF and internal frequencies occurs when the frequency is $100 \mathrm{~Hz}$ and lasts for 30 minutes (Fig. 6).

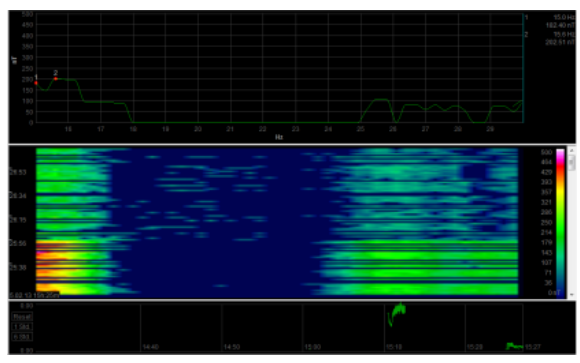

Fig. 6. Spectra of photons reflected from the treated product with the treatment frequency of $100 \mathrm{~Hz}$ and duration of $\mathbf{3 0}$ minutes

In order to determine the safe distance from the emitter, the effect of LF EMF with 45 and $100 \mathrm{~Hz}$ frequencies was studied on Escherichia coli culture, in physiological solution placed intothe shielded chamber out outside the chamber at the distances of 0.5, 1.0, 1.5 and $2.0 \mathrm{~m}$ from the emitter (Fig. 7 and 8).

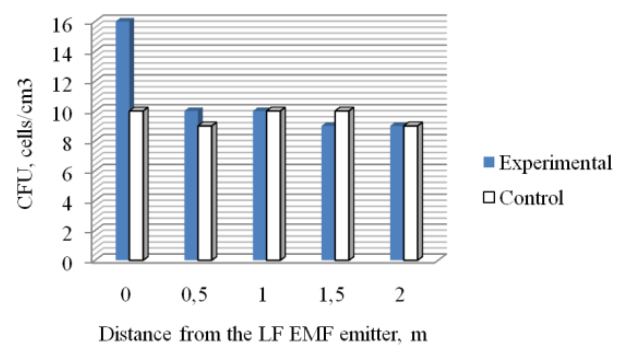

Fig. 7. Influence of the LF EMF at a frequency of $45 \mathrm{~Hz}$ on the culture of Escherichia coli inside and outside the device

It was found that LF EMF exposure at a frequency of 45 $\mathrm{Hz}$ and duration of 60 minutes of the sample under the emitter caused a rapid increase in the number of colonies. In the sample located at a distance of $0.5 \mathrm{~m}$ from the emitter, the number of colonies increased rapidly, and at distances from 1.0 to $2.0 \mathrm{~m}$ no significant changes in the number of colonies were observed. 
The analysis of electromagnetic radiation ("Impul's"device by Soeks), the following indicators were noted at the control points: at a distance of $0.5 \mathrm{~m}$ from the emitter • 9.56 microtesla; $1.0 \mathrm{~m} \cdot 5.10$ microtesla; $1.5 \mathrm{~m}$ - 3.24 microtesla and $2.0 \mathrm{~m} \cdot 2.56$ microtesla, with the maximum permissible limit of 10 microtesla. It was stated that the exposure at a frequency of $100 \mathrm{~Hz}$ for 30 minutes caused the death of the investigated microflora in the sample under the emitter. A slight change in the number of colonies is observed at a distance of $0.5 \mathrm{~m}$ from the emitter, and at the distance from 1.0 to $2.0 \mathrm{~m}$ no significant changes in the number of colonies were observed (Fig. 8). When analyzing the electromagnetic radiation at the control points, the following indicators were recorded: at a distance of $0.5 \mathrm{~m}$. 9.06 microtesla, at $1.0 \mathrm{~m} \cdot 6.21$ microtesla, at $1.5 \mathrm{~m} \cdot 4.54$ microtesla, and at $2.0 \mathrm{~m} \cdot 2.66$ microtesla. It was established that the safe distance from the emitter is $0.5 \mathrm{~m}$.

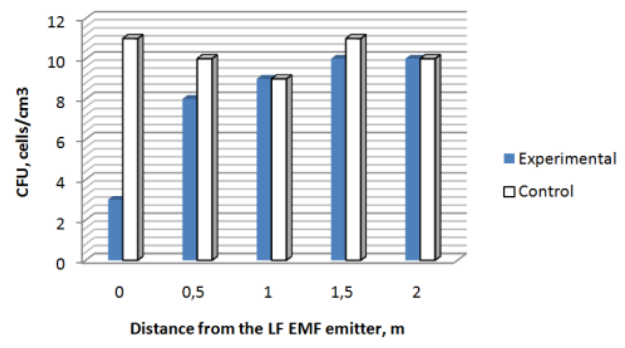

Fig. 8. Influence of the LF EMF at a frequency of 100 $\mathrm{Hz}$ on the culture of Escherichia coli inside and outside the device

Further, we investigated the LF EMF influence on the properties of fresh sausage meat with a frequency of $100 \mathrm{~Hz}$ and a duration of $30 \mathrm{~min}$. The muscles from the pork and beef hip parts were placed under the LF EMF emitter and treated at a frequency of $100 \mathrm{~Hz}$ for 30 minutes. Under the influence of LF EMF, a decrease in microbiological contamination of the samples was observed, as shown in Table 2.

Table - II: Change in microbial contamination of fresh sausage meat after LF EMF treatment

\begin{tabular}{|l|c|c|c|}
\hline \multicolumn{1}{|c|}{ Sample } & $\begin{array}{c}\text { Treatment duration, } \\
\text { min }\end{array}$ & $\begin{array}{c}\text { Frequency, f, } \\
\text { Hz }\end{array}$ & $\begin{array}{c}\text { Total viable } \\
\text { count, CFU/g }\end{array}$ \\
\hline Beef (control) & - & - & $2.1 \cdot 10^{5}$ \\
\hline Beef & 30 & 100 & $1.1 \cdot 10^{2}$ \\
\hline Pork (control) & - & - & $9.4 \cdot 10^{4}$ \\
\hline Pork & 30 & 100 & $1.0 \cdot 10^{2}$ \\
\hline
\end{tabular}

Exposure to EMF changes the membrane permeability of myofibrils, causes the moisture redistribution in the colloidal system of beef and pork muscle tissue, changes the degree of proteins dispersion(Koshchaev et al. 2016; Plutakhin2016). All that affects the $\mathrm{pH}$ and water-binding capacity (WBC) of meat (Table 3).

Table - III: LF EMF influence on the pH and WBC of meat

\begin{tabular}{|l|c|c|c|c|}
\hline Sample & $\begin{array}{c}\text { Treatment } \\
\text { duration, } \\
\text { min }\end{array}$ & $\begin{array}{c}\text { Frequency f, } \\
\text { Hz }\end{array}$ & pH & WBC, \% \\
\hline Beef (control) & - & - & $6.10 \pm 0.1$ & $68.00 \pm 1.12$ \\
\hline Beef & 30 & 100 & $5.90 \pm 0.07$ & $63.50 \pm 1.05^{*}$ \\
\hline Pork (control) & - & - & $5.5 \pm 0.1$ & $56.00 \pm 1.58$ \\
\hline Pork & 30 & 100 & $5.3 \pm 0.08$ & $52.30 \pm 0.4^{*}$ \\
\hline \multicolumn{4}{r|}{ * P $<0.05$}
\end{tabular}

The microstructural analysis of muscle tissue exposed to
LF EMF with a frequency of $100 \mathrm{~Hz}$ and a duration of 30 minutes shows that pork muscle tissue is characterized by destructive changes, sarcolemma damage, and fragmentation of muscle fibers (Fig. 9 and 10). The muscle fibers often become disconnected, which can be seen as light spaces, not colored with hematoxylin and eosin,appearing around then, or are closely pulled together (Khvylya2002).

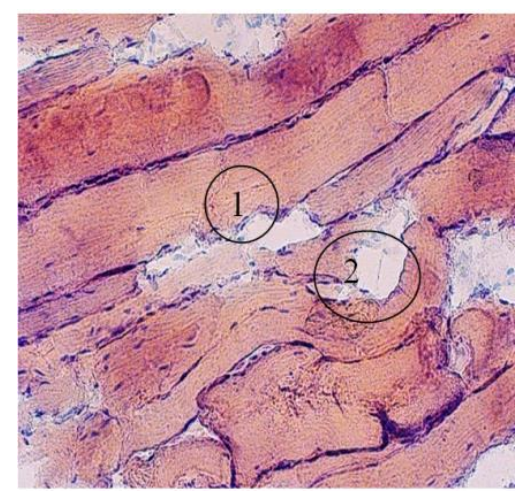

Fig. 9. Lengthwise section of pork muscle fibers. Cross cracks and fragmentation. Colored with hematoxylin and eosin. Zoom $\times$ 200:1 - epimysium ruptures; 2 muscle fibers fragmentation

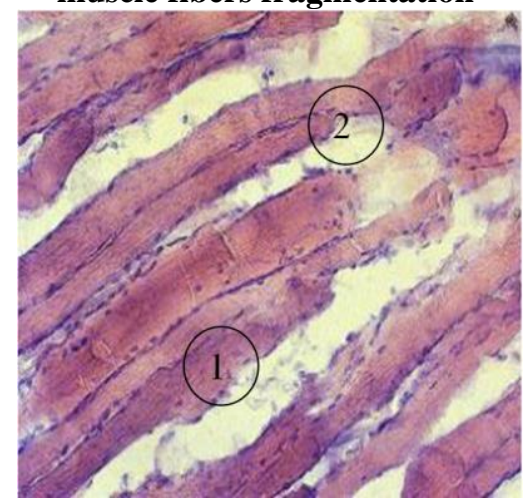

Fig. 10. Lengthwise section of beef muscle fibers. Colored with hematoxylin and eosin. Zoom $\times 200: 1-$ shredding of myofibrillar fascicles; 2 - muscle fibers fragmentation

The analysis of beef muscle tissue, after electromagnetic treatment with a frequency of $100 \mathrm{~Hz}$ during 30 minutes, showed that the arrangement of individual fibers in the primary fascicle is rather loose, with a noticeable light space near the endomysium. The boundary between individual muscle fibers is not always clearly distinguishable (Fig. 10). Destructive changes in muscle tissue, as a result of electromagnetic exposure, are clearly visible and are related to the resonance between the external frequencies and the internal muscle tissue frequency (Nesterenko et al 2017a).

In order to intensify the technological process of summer sausages production, the starter cultures are used. Their action is due to the formation of specific biologically active components like organic acids, enzymes, etc. To determine the effect of the introduced LF EMF treated starter cultures on the model system, we used test ground meat consisting of $60 \%$ of refrigerated beef and $40 \%$ of refrigerated pork.

Published By:

Blue Eyes Intelligence Engineering

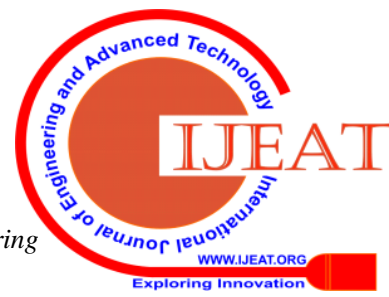


Fresh sausage meat was preliminarily ground on a sausage meat chopper with the grate diameter $\mathrm{d}=3 \mathrm{~mm}$. The starter cultures "Al'mi-2" by Almi were used as the experimental microflora. In compliance with the recommendations of the starter cultures manufacturer, the control group was activated in $100 \mathrm{~cm} 3$ of water with a temperature of $25-30^{\circ} \mathrm{C}$, left for 30 minutes, until it was completely dissolved, and added to the test ground meat. The starter cultures for the experimental group activated in the same way as for the control group, but after the dissolution, they were treated with LF EMF at a frequency of $45 \mathrm{~Hz}$ for 60 $\min$.

Previous experiments indicated that LF EMF can accelerate the microflora development. In this regard, the optimal dose of the LF EMF-treated starter cultures was determined (Table 4).

Table - IV: Growth dynamics of a starter microflora

\begin{tabular}{|c|c|c|c|c|c|}
\hline \multirow{2}{*}{$\begin{array}{c}\text { Amount of starter } \\
\text { cultures, g/100 kg } \\
\text { of ground meat }\end{array}$} & \multicolumn{5}{|c|}{ Duration, hrs } \\
\cline { 2 - 6 } & $\mathbf{0}$ & $\mathbf{5}$ & $\mathbf{6}$ & $\mathbf{9}$ & $\mathbf{1 2}$ \\
\hline 20 (control) & $4.8 \cdot 10^{5}$ & $5.7 \cdot 10^{5}$ & $6.7 \cdot 10^{5}$ & $8.7 \cdot 10^{5}$ & $1.0 \cdot 10^{6}$ \\
\hline 17.5 & $5.2 \cdot 10^{5}$ & $6.8 \cdot 10^{5}$ & $8.1 \cdot 10^{5}$ & $1.7 \cdot 10^{6}$ & $2.4 \cdot 10^{6}$ \\
\hline 15.0 & $4.9 \cdot 10^{5}$ & $6.1 \cdot 10^{5}$ & $7.4 \cdot 10^{5}$ & $9.5 \cdot 10^{5}$ & $1.6 \cdot 10^{6}$ \\
\hline 12.5 & $4.1 \cdot 10^{5}$ & $4.7 \cdot 10^{5}$ & $5.8 \cdot 10^{5}$ & $7.1 \cdot 10^{5}$ & $8.2 \cdot 10^{5}$ \\
\hline 10.0 & $3.7 \cdot 10^{5}$ & $4.1 \cdot 10^{5}$ & $4.7 \cdot 10^{5}$ & $5.2 \cdot 10^{5}$ & $6.1 \cdot 10^{5}$ \\
\hline
\end{tabular}

Excessively rapid growth of starter cultures may lead to acidification of ground meat, while weak growth results in inefficient performance of microflora (Timoshenko et al 2016). In this regard, the dose was determined experimentally: $15 \mathrm{~g}$ of starter cultures per $100 \mathrm{~kg}$ of ground meat.

Changes in physical-chemical and functional-technological indices of fresh sausage meat are important indicators that form the quality of raw sausage meat (Timoshenko et al 2016). It was stated that the WBC of the control sample of the test ground meat exceeds the WBC of experimental one with the addition of the LF EMF-treated starter cultures. The WBC of the experimental sample tends to decrease in comparison with the control one (Fig. 11).

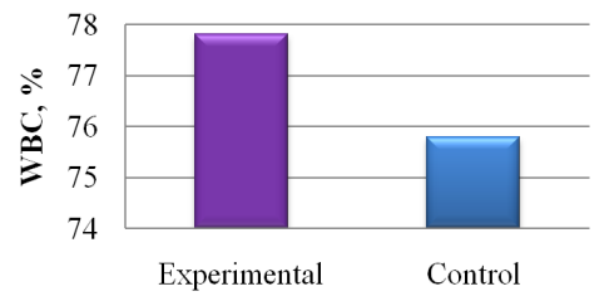

Fig. 11. Water-binding capacity of test ground meat samples

In the formation of a solid structure of ground meat, the stickiness or adhesion is of great importance. It was established (Fig. 12) that the introduction of LF EMF-treated starter cultures (experiment sample) increases the stickiness of the test ground meat by $15.3 \%$ if compared to the control sample.

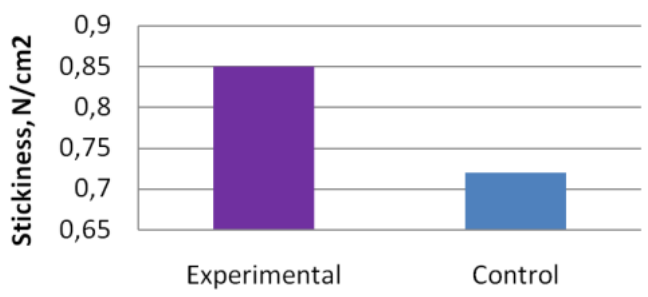

Fig. 12. Stickiness of the ground meat after starter cultures introduction

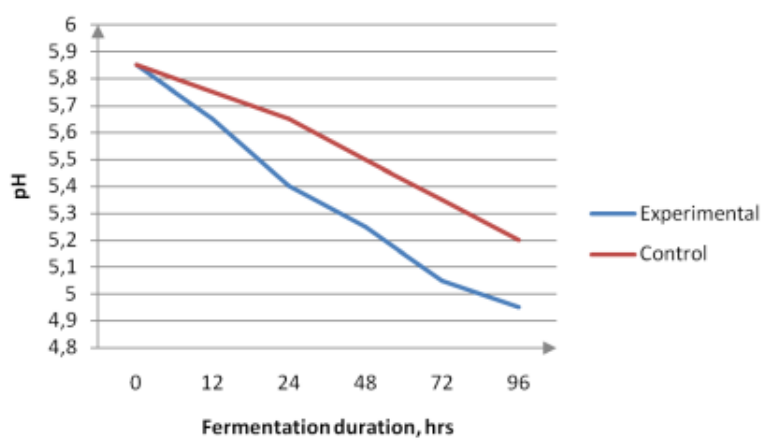

Fig. 13. Dynamics of the $\mathrm{pH}$ of a test ground meat sample

Fig.14 shows the dynamics of lactic acid growth in the test samples. The amount of lactic acid in the experimental sample exceeded that in the control sample by $10 \%$ after 12 hours of the test ground meat ageing. After five days, the difference was $17.5 \%$, which indicates a faster accumulation of lactic acid in the experimental group.

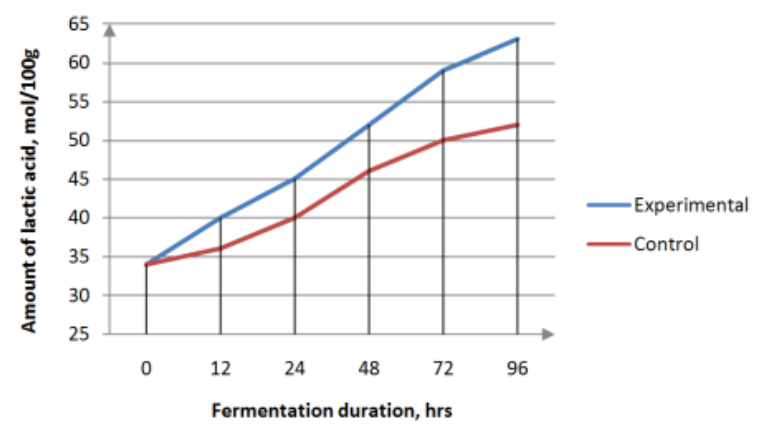

Fig.14. Dynamics of lactic acid accumulation in the test ground meat sample

One of the most important indices of starter cultures efficiency is their proteolytic activity. It is determined by the degree of meat proteolysis. Analysis of the amino-acid composition showed a $6.8 \%$ increase in amino-acids in the experimental sample, compared with the control one.

The accumulation of a water-soluble fraction and loosely bound moisture contributes to the effective drying of sausages due to the transition of moisture from tightly bound to loosely bound form. The obtained results of studies of the LF EMF effect on WBC, $\mathrm{pH}$ and stickiness of test ground meat also indicate more efficient performance of starter cultures activated by LF EMF. 
For the testing of the summer sausages production technology involving LF EMF, the authors used the sausage recipe "Tikhoretskaya" TS 9213-006-00422020-2002.

To perform the comparative evaluation of the experimental group of sausages two batches were produced, differing in their compounds by the following components: control group - starter cultures “Al' mi-2” • 20 g per $100 \mathrm{~kg}$ of ground meat; experimental group - LFEMF-activated starter cultures “Almi-2” • 15 g per $100 \mathrm{~kg}$ of ground meat, fresh sausage meat with LF EMF pre-treatment (Nesterenko 2014). The experiment monitored the $\mathrm{pH}$ values (Fig. 15), the moisture content (Fig. 16), and the quantity of the total viable count, CFU/g, of the product (Table 5).

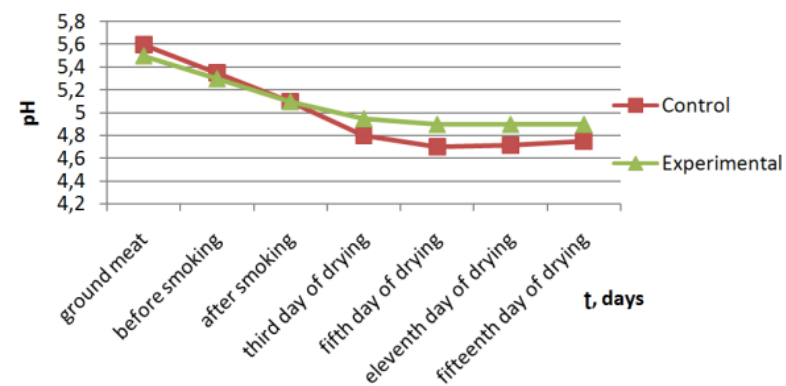

Fig. 15. Changes in the $\mathrm{pH}$ value during the process of settling, smoking and drying of summer sausages

The decrease in the $\mathrm{pH}$ of sausages of the control group occurs slowly, with acceleration at the beginning of drying. The decrease is caused by the accumulation of lactic acid microorganisms. Reducing the $\mathrm{pH}$ of sausages in the experimental group occurs rapidly, evenly, without excessive acidification of the ground meat.

It was found that the experimental sample looses moisture more intensively (Fig. 16). This happens due to emerging micropores in fresh sausage meat after exposure to LF EMF. This fact is proved by microstructural analysis of the ready-to-use products.

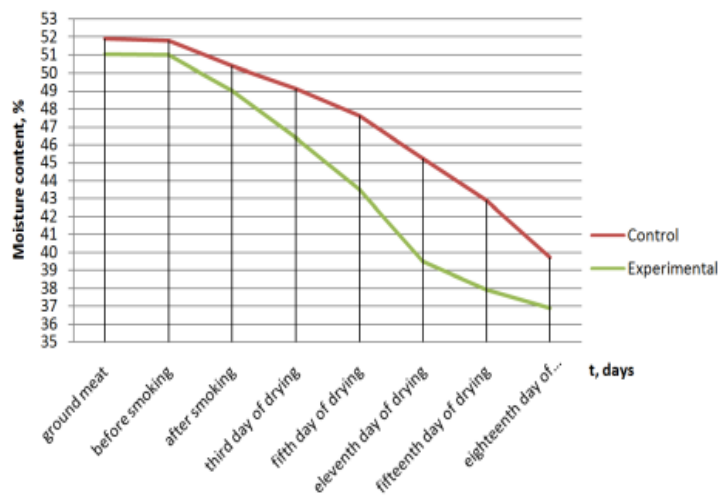

Fig. 16. Reduction of moisture content in the process of sausages drying

Intensive growth of microflora in samples of summer sausages of the experimental batch is determined by preliminary activation of the starter cultures with LF EMF, the main part of the microflora being the introduced starter cultures.
Table - V: Quantitative changes in the microflora of summer sausages

\begin{tabular}{|l|c|c|}
\hline \multirow{2}{*}{\multicolumn{1}{|c|}{ Study period }} & \multicolumn{2}{c|}{$\begin{array}{c}\text { Amount of microflora, total viable } \\
\text { count, CFU/g }\end{array}$} \\
\cline { 2 - 3 } & Control & Experiment \\
\hline Ground meat after preparation & $3.3 \cdot 10^{5}$ & $2.1 \cdot 10^{6}$ \\
\hline Sausage before smoking & $3.5 \cdot 10^{5}$ & $2.4 \cdot 10^{6}$ \\
\hline Sausage after smoking & $1.2 \cdot 10^{6}$ & $9.0 \cdot 10^{5}$ \\
\hline On the third day of drying & $8.1 \cdot 10^{5}$ & $1.0 \cdot 10^{5}$ \\
\hline On the fifth day of drying & $9.3 \cdot 10^{4}$ & $2.0 \cdot 10^{4}$ \\
\hline On the eleventh day of drying & $5.1 \cdot 10^{3}$ & $4.0 \cdot 10^{2}$ \\
\hline On the fifteenth day of drying & $8.4 \cdot 10^{2}$ & $3.0 \cdot 10^{2}$ \\
\hline
\end{tabular}

The histological examination of the ready-to-use sausages showed that the muscle fibershave cross cracks and ruptures that capture both the fibrillar protein complex and the sarcolemma. A large part of muscle fibers is fragmented (Fig. 17).

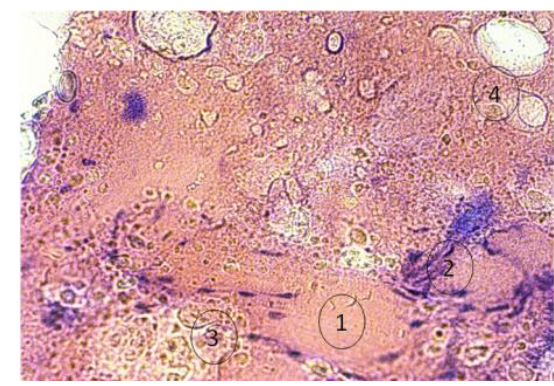

Fig. 17. Muscle fiber fragments in the summer sausage. Colored with hematoxylin and eosin Zoom $\times 200: 1$. muscle fiber fragments; 2 - microorganisms; 3 . micropores; 4 • fat saccules

There are a great number of micropores between the muscle fibers. Individual microbial cells of the starter material are found between the ground meat particles, cover the inside surface of ground meat pores and are found in large quantities.

According to the protocols of the testing center of " Myasokombinat Tikhoretsky” CJSC No. 47 • 49, 56, 65, the experimental batch of summer sausages complies with physical-chemical, microbiological, toxicological, and organoleptic parameters, as well as to the expiry dates by Technical Standard 9213-006-00422020-2002. The finished product was organoleptically assessed by specialists of the "Myasokombinat Tikhoretsky" CJSC. Experimental sample had stronger flavor and taste (Fig. 18).

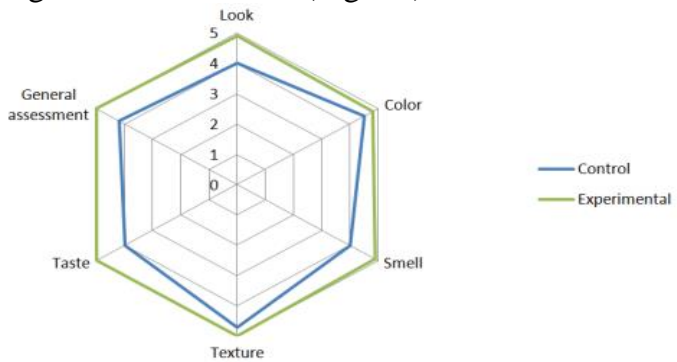

Fig. 18. Organoleptic profile of the ready-to-use sausage on a scale from one to five 
The tasting revealed more dense structure of the experimental sample. The tasting information is substantiated by studies of the structural and mechanical characteristics of the ready product. For this purpose, the shear stress of a ready product was studied. The shear stress of the experimental sample was $559.59 \mathrm{kPa}$, of the control sample • $478.56 \mathrm{kPa}$. The research results reveal a denser structure of the summer sausages of the experimental group.

Along with such qualitative indicators as chemical composition, microbiological, physical-chemical, biochemical, and organoleptic parameters, the biological value of a ready product is also of great importance. It was tested on white laboratory rats. This experiment was conducted in the vivarium of North Caucasus Scientific Research Institute of Livestock Husbandry during 28 days. The experiment used two groups of five rats in each, aged 1 month. The first group was the control one, the second was the experimental one. The diets for growing rats were formed in accordance with the laboratory rats' demands in nutrients.

The obtained data of the rats' growth parameters (Fig. 19) indicated the average daily weight gain for 28 days in the experimental group of $3.97 \mathrm{~g}$, or $107.5 \%$ if compared with the control group.

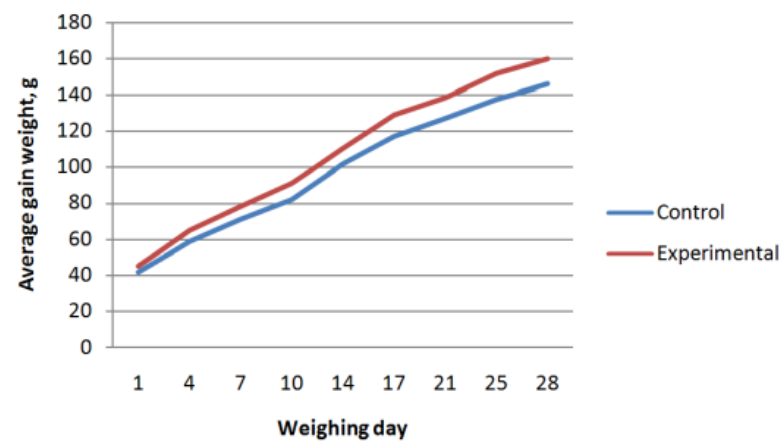

Fig. 19. Dynamics of body weight of experimental rats

After the weighing, the experimental and control rats were killed by single-stage decapitation.

The biochemical parameters of the rats' blood wereanalyzed on a Vitalab Flexor Junior biochemical analyzer (Netherlands). The following parameters were analyzed during the experiment: leukocytes, leukogram, eosinophils, stab neutrophils, segmented neutrophils, lymphocytes, monocytes, red blood cells, hemoglobin, hematocrit, platelets, platelecrit, protein, albumins, globulins $(\alpha, \beta, \gamma)$, cholesterol, aspartate transaminase, alanine transaminase, calcium, phosphorus, triglycerides, alkaline phosphatase, iron (Table 6).

Table - VI: Morphological and biochemical characteristics of rats' blood

\begin{tabular}{|l|c|c|}
\hline \multirow{2}{*}{\multicolumn{1}{|c|}{ Indicators }} & \multicolumn{2}{c|}{ Groups } \\
\cline { 2 - 3 } & Control & Experiment \\
\cline { 2 - 3 } & $\mathbf{M} \pm \mathbf{m}$ & $\mathbf{M} \pm \mathbf{m}$ \\
\hline Leukocytes, ths/l & $8.8 \pm 0.49$ & $8.3 \pm 0.32$ \\
\hline Leukogram, \% of eosinophils & $2.2 \pm 0.09$ & $1.8 \pm 0.08$ \\
\hline Stab neutrophils, \% & $0.6 \pm 0.01$ & $0.8 \pm 0.02$ \\
\hline Segmented neutrophils, \% & $25.2 \pm 1.5$ & $16.2 \pm 1.2 *$ \\
\hline Lymphocytes, \% & $71.2 \pm 3.8$ & $80.4 \pm 4.1$ \\
\hline Monocytes, \% & $0.8 \pm 0.03$ & $0.8 \pm 0.04$ \\
\hline Red blood cells, ml/l & $4.9 \pm 0.12$ & $5.1 \pm 0.13$ \\
\hline Hemoglobin, g/l & $135.0 \pm 8.6$ & $136.9 \pm 5.7$ \\
\hline
\end{tabular}

\begin{tabular}{|l|c|c|}
\hline Hematocrit, \% & $31.0 \pm 1.3$ & $33.2 \pm 1.5$ \\
\hline Platelets, ths/l & $567.2 \pm 23.5$ & $747.8 \pm 39.8$ \\
\hline Platelecrit, \% & $0.375 \pm 0.0075$ & $0.495 \pm 0.0089$ \\
\hline Cell-color ratio, units & $0.71 \pm 0.031$ & $0.71 \pm 0.025$ \\
\hline Protein, g/l & $72.1 \pm 4.3$ & $74.5 \pm 5.0$ \\
\hline Albumins, \% & $27.5 \pm 1.1$ & $25.6 \pm 1.3$ \\
\hline Globulins, \% & - & - \\
\hline$\alpha$ & $40.7 \pm 2.3$ & $40.2 \pm 1.9$ \\
\hline$\beta$ & $17.4 \pm 0.8$ & $16.6 \pm 0.9$ \\
\hline$\gamma$ & $14.3 \pm 0.5$ & $17.6 \pm 0.5$ \\
\hline Cholesterol, mmol/l & $2.2 \pm 0.13$ & $2.1 \pm 0.11$ \\
\hline AST, units & $331.6 \pm 15.1$ & $257.6 \pm 12.9$ \\
\hline ALT, units & $87.0 \pm 3.8$ & $76.6 \pm 2.9$ \\
\hline Calcium, mmol/l & $3.2 \pm 0.13$ & $3.1 \pm 0.12$ \\
\hline Phosphorus, mmol/l & $3.6 \pm 0.11$ & $3.7 \pm 0.1$ \\
\hline Triglycerides, mmol/l & $1.0 \pm 0.03$ & $1.7 \pm 0.04$ \\
\hline Alkaline phosphatase, units & $1290.4 \pm 53.3$ & $1352.6 \pm 45.2$ \\
\hline Iron, $\mu m o l / l$ & $68.3 \pm 3.7$ & $50.7 \pm 2.9$ \\
\hline
\end{tabular}

Note: * - $\mathrm{P} \leq 0.05$ if compared to the control group.

Substituting a part of a diet for summer sausages had no significant effect on the number of leukocytes. Thus, there were no inflammatory processes in animal organisms. These indexes practically coincide and do not deviate from the norm for the species.

Higher eosinophil count may point at an allergic reaction to food components. In the control group, an average eosinophil count exceeded the normal one. Reduction of this index in the experimental group indicates a decrease in allergic burden on animals.

A decrease in the count of segmented neutrophils in the experimental group may point at inflammatory processes in animal organisms. As the number of leukocytes is normal,feeding the animals with sausage containing a large amount of salt and sodium nitrite could affect the result.

The average value of the cell-color ratio in rats' blood (indicating the relative content of hemoglobin in one red blood cell) was within the same limit in both groups and without deviations from the norm.

An increase in the total protein content in experimental rats' blood indicates a good assimilability of the proteins in the diet. The authors assume that the decrease in enzyme activity is not related to possible diseases and abnormalities in the organism functioning. It may be explained by the fact that, under the influence of the starter cultures, partial albuminolysis takes place, which promotes faster and more effective assimilability of proteins in rats.

The increase in triglyceride content in the experimental group indicates a high content of fat in the animals' diet. At the same time, the level of cholesterol in experimental rats does not increase and corresponds to the values of the control group. Therefore, one may conclude that there are no functional load on liver of experimental animals and no metabolic shifts towards pathology. The Fe index lowered by $17.6 \mu \mathrm{mol} / 1$ in the experimental group indicates a more complete assimilation of Fe by the rats. This indicator in the experimental group is normal, without deviations. Scientists found that the majority of pathological conditions are based on various violations of chemical transformations that occur in the body. Modern biochemical analysis allows detecting changes in the activity of blood enzymes in case of various diseases. 
It was established that in clinically healthy animals the activity of some blood enzymes is relatively low, especially compared to their activity in tissues.

Alanine transaminase (ALT) and aspartate transaminase (AST) are usually found in all organs and tissues of animals. Their maximum activity is observed in skeletal muscles, myocardium and, usually, liver.

Transaminase is an intracellular enzyme, which, as a rule, is found in blood serum in small amounts. The increased transaminase activity is observed in tissues with intensive protein synthesis.

One of the ALT functions is transamination, that is, reversible transfer of amino-groups of amino-acids.

Increased activity of AST is manifested in cases of acute and chronic liver diseases. Liver diseases also increase the ALT activity.

As can be seen from Table 6, the AST and ALT activities in the experimental and control groups decreased by 74 units and 10.4 units respectively, compared to the control group. A decrease in the activities of these enzymes may indicate that there is no toxic load on hepatocytes.

Alkaline phosphatase is usually found in all organs and tissues of animals. The greatest amounts are observed in bone tissue, liver, kidneys, and intestinal mucous membrane.

The authors noted a high activity of the enzyme in both groups, but the most significant increase was observed in the rats of the experimental group. There, the activity of alkaline phosphatase in the group fed with summer sausage was 1352.6 units, while in the control group it was 1290.4 units.

We may suggest that the activity of alkaline phosphatase is physiological and is related to the intensive growth of bone tissue in young animals. This index is usually higher in immature animals. It is substantiated by some increase in the counts of $\mathrm{Ca}$ and $\mathrm{P}$, which is also due primarily to the animals' age.

Introducing the summer sausage into the diet of experimental rats positively affects the condition of animals, which is confirmed by the integral results of biochemical blood tests.

\section{CONCLUSION}

1. The conducted research studied the influence of electromagnetic field on the microflora of fresh sausage meat. The field had a range from 10 to $110 \mathrm{~Hz}$ and the duration of the exposure from 15 to $60 \mathrm{~min}$. It is revealed that the peak of microflora development occurs at the frequency of $45 \mathrm{~Hz}$ and the treatment duration of 60 minutes. The inhibition of microflora development is observed under the EMF action at the frequency of $100 \mathrm{~Hz}$ and the duration of 30 minutes.

2. It was found that if refrigerated beef and pork are exposed to LF EMF at the frequency of $100 \mathrm{~Hz}$ during 30 minutes, the microstructural examination shows partial destruction of the meat cellular structure. It causes a decrease in WBC of meat (for beef - from $68.00 \pm 1.12 \%$ to $63.00 \pm 1.05 \%$, for pork - from $56.00 \pm 1.58 \%$ to $52.30 \pm 0.4 \%$ ). The microbiological contamination of beef is reduced from $2.1 \cdot 10^{5}$ to $1.1 \cdot 10^{2} \mathrm{CFU} / \mathrm{g}$, of pork - from $9.4 \cdot 10^{4}$ to $1.0 \cdot 102 \mathrm{CFU} / \mathrm{g}(\mathrm{P} \leq 0.05)$. The $\mathrm{pH}$ value of meat is slightly shifted to acidic: for beef - from $6.10 \pm 0.1$ to
$5.90 \pm 0.73$, for pork - from5.50 \pm 0.1 to $5.30 \pm 0.85(\mathrm{P} \geq 0.05)$.

3. It was established that treatment of "Al'mi-2" preparation starter cultures with LF EMF at the frequency of $45 \mathrm{~Hz}$ for 60 minutes stimulates their growth; when EMF-treated starter cultures are added to test ground meat, the meat $\mathrm{pH}$ reduces significantly from 5.85 to 4.95 , the number of amino-acids increases by $6.8 \%$, the WBC decreases from $81.78 \%$ to $77.80 \%$, the WRC • by $4.8 \%$, the stickiness of the ground meat increases by $15.3 \%$.

4. The paper studied the effect of LF EMF treatment of the fresh sausage meat and starter cultures on the rate of summer sausages drying. It was found that after using LF EMF, the duration of the technological process of the summer sausages production is reduced by 7 days, and makes 14 days.

5. The amendments were made to the technological instruction for the summer sausages production. An industrial approbation of the improved technology was carried out at "Myasokombinat Tikhoretsky" CJSC, the city of Tikhoretsk, Krasnodar Territory. According to the protocols of the quality assessment made by the testing center of "Myasokombinat Tikhoretsky" CJSC No. 47 • 49, 56, 65 , the experimental batch of summer sausages complies with the physical-chemical, microbiological, toxicological, and organoleptic parameters, as well as to the expiry datesby TS 9213-006-00422020-2002.

\section{ACKNOWLEDGMENT}

The reported study was funded by RFBR according to the research project No. 16-48-230543/16.

\section{REFERENCES}

1. Antipova L.V., Glotova I.A., Rogov I.A. (2001) Metody issledovaniya myasa i myasnykh produktov [Research methods for meat and meat products]. Kolos, Moscow.

2. Antonov B.I. (2001) Laboratornye issledovaniya $\mathrm{v}$ veterinarii. Biokhimicheskiye i mikologicheskiye [Laboratory research in veterinary medicine. Biochemical and mycological]: reference book. Agropromizdat, Moscow.

3. Baryshev M.G., Naumov G.N., Dmitriev V.I., Vasilyev N.S. (2008) Vozdeystviye nizkochastotnogo elektromagnitnogo polya na prokarioticheskiye i eukarioticheskiye mikroorganizmy [Effect of low-frequency electromagnetic field on prokaryotic and eukaryotic microorganisms]. Nauka Kubani [Science of Kuban] 4:17-22.

4. Borisenko A.A., Shiryaeva E.A., Kanev M.Yu., Shepilov E.V. (2002) Pat. No. 2183318 Russian Federation MTZh, G01N3/48/. Device for determining the structural and mechanical properties of food products. Applier and patent holder: North Caucasus State Technical University, No. 2000120080/28, Iss. 27.07.2000, Pub. 10.06.2002. Bul. No. 16.

5. Dumin M.V., Potapov K.V., Yarmonov A.M. (2002) Startovye kul'tury dlya myasnykh delikatesov [Starter cultures for meat gourmet products] Myasnaya industriya [Meat Industry] 5:23-24.

6. GOST 10444.15-94 (1994) Food products. Methods for determining the amount of mesophilic aerobic and facultative-anaerobic microorganisms. Izd-vo standartov, Moscow.

7. GOST 9793-74 (1990) Meat products. Methods for determining the moisture content. Izd-vo standartov, Moscow.

8. GOST R 50258 - 92 (1993) Mixed feed rations for laboratory animals. Standartinform, Moscow.

9. GOST R 51478-99 (2005) Meat and meat products. Control method for determining the concentration of hydrogen ions $(\mathrm{pH})$. Izd-vo standartov, Moscow.

10. Hu Yo, Xia W, Ge Ch (2014) Effect of mixed starter cultures fermentation on the characteristics of silver carp sausages. World Journal of Microbiology and Biotechnology 12:1-11.

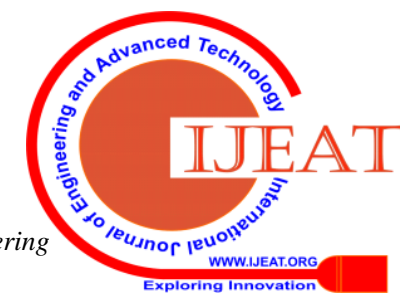


11. Khramchenko S.V. (2007) Sovershenstvovaniye tekhnologii polusukhikh fermentirovannykh kolbas [Improving the technology of semi-dry fermented sausages]: abstrast of PhD Diss. (Tech. Sci.). Stavropol.

12. Khvylya S.I. (2002) Nauchno-metodicheskiye rekomendatsii po mikrostrukturnomu analizu myasa i myasnykh produktov [Scientific and methodological recommendations on microstructural analysis of meat and meat products]. RASKhN, Moscow.

13. Khvylya S.I., Pchelkina V.A. (2007) Vozmozhnosti analiza sostava myasnogo syrya i gotovoy produktsii. Razrabotka novykh GOST na metody issledovaniya [Opportunities for analyzing the composition of fresh sausage meat and ready-to-use products. Development of new GOST for research methods]. Myasnaya industriya [Meat Industry] 9:9-12.

14. Khvylya S.I., Pchelkina V.A. (2013) Gosudarstvennaya standartizatsiya metodov issledovaniya $\mathrm{V}$ myasnoy promyshlennosti [State standardization of research methods in meat industry]. Myasnye tekhnologii [Meat Technology] 1:34-37.

15. Koshchaev A.G., Shchukina I.V., Semenenko M.P., Sergeeva A.K., Vasilevich K.V. (2016) Amino acid profile of meat of specialized beef breeds. Research Journal of Pharmaceutical, Biological and Chemical Sciences 7(5):670-676.

16. Sydykova M., Nurymkhan G., Gaptar S., Rebezov Y., Khayrullin M., Nesterenko A., Gazeev I. Using of lactic-acid bacteria in the production of sausage products: modern conditions and perspectives. International Journal of Pharmaceutical Research, 2019; 11(1): 1073-1083.

17. Koshchaev A.G., Nesterenko A.A., Shhalahov D.S., Lysenko A.A., Shabunin S.V., Lorets O.G., Goushchin V.V. Model minced poultry meat biomodification with starter cultures. International Journal of Engineering and Advanced Technology, 2019; 9(1): 4987-4992.

18. Nesterenko A.A., Kenijz N.V., Shlykov S.N. (2016) Biological assessment of summer sausage with preprocessing for starter cultures and meat raw by electromagnetic field of low frequencies. Research Journal of Pharmaceutical, Biological and Chemical Sciences 7(1):1214-1220

19. Nesterenko A., Koshchaev A., Kenijz N., Omarov R., Shlykov S Properties and compatibility of microflora for creating starter cultures in sausage production technology. International Journal of Recent Technology and Engineering, 2019; 8(4): 249-253.

20. Nesterenko A., Koshchaev A., Kenijz N., Omarov R., Shlykov S. Development of ham technology using starter cultures. International Journal of Recent Technology and Engineering, 2019; 8(4): 9834 9837.

21. Oboturova N.P., Kozhevnikova O.N., Barybina L.I., Nagdalyan A.A. (2012) Razryadno-tipulsnoye vozdeystviye dlya intensifikatsii posola myasa [Discharge-pulse effect for intensifying the meat brining]. Myasnaya industriya [Meat Industry] 2:32-35.

22. Plutakhin G.A., Koshchaev A.G., Donnik I.M. (2016) Quality assessment of chicken meat by analysis-of-variance method. Research Journal of Pharmaceutical, Biological and Chemical Sciences 7(3):2293-2299.

23. Radchenko V.V., Ilnitskaya E.V., Rodionova A.S., Shuvaeva T.M. Lysenko Yu.A., Plutakhin GA, Manolov AI, Donnik IM, Koshchaev AG (2016) Identification of autochthonous strains as a basis for the development of the therapeutic and profylactic probiotics. Russian Journal of Biopharmaceuticals 8(1):3-12.

24. Shipulin V.I., Lupandina N.D., Dadyan N.K., Zinovchenko A.A. (2010) Osnovnye napravleniya ispolzovaniya pishchevykh preparatov, intensifitsiruyushchikh tekhnologicheskiy protsess proizvodstva syrokopchenykh kolbas [Main directions of using food agents intensifying the technological process of summer sausages production]. Vestnik Severo-Kavkazskogo gosudarstvennogo tekhnicheskogo universiteta [Bulletin of North Caucasus State Technical University] 3(24).

25. Starostina N.G., Koshchaev A.G., Ratner E.N., Tsiomenko A.B. (1997a) Assessment of cell-surface hydrophobicity in methanotrophic bacteria by their adherence to hydrocarbons. Microbiology 66(2):151-156.

26. Starostina N.G., Koshchaev A.G., Ratner E.N., Tsiomenko A.B. (1997b) Cell surface hydrophobicity in methanotrophic bacteria by their adherence to hydrocarbons. Mikrobiologiya [Microbiology] 66(2):185-191.

27. Okuskhanova E., Rebezov YA., Khayrullin M., Nesterenko A., Mironova I., Gazeev I., Nigmatyanov A., Goncharov A. Low-calorie meat food for obesity prevention. International journal of pharmaceutical research, 2019; 11 (1): 11589-11592.

28. Tsinpaev M.A. (2008) Sovershenstvovaniye tekhnologii syrokopchenykh kolbas na osnove otsenki "Bar'ernykh" znacheniy pokazateley kachestva [Improvement of technology of summer sausages on the basis of an assessment of "barrier" values of quality indicators]: PhD diss. (Tech. Sci.). Moscow.

\section{AUTHORS PROFILE}

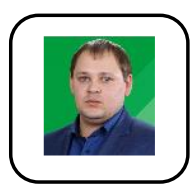

Anton Nesterenko candidate of technical sciences, associate professor of the department of technology for storage and processing of livestock products, Kuban State Agrarian University named after I.T. Trubilin.

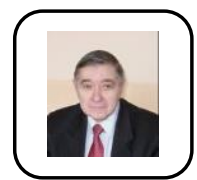

Viktor Goushchin doctor of agricultural sciences, professor, All-Russian Scientific Research Institute of Poultry Processing Industry - branch of the Federal State Budget Scientific Institution Federal Scientific Center "All-Russian Research and Technological Poultry Institute" of the Russian Academy of Sciences.

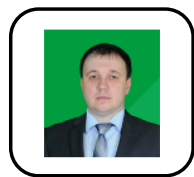

Andrey Koshchaev doctor of biological sciences, professor, department of biotechnology, biochemistry and biophysics, Kuban State Agrarian University named after I.T. Trubilin.

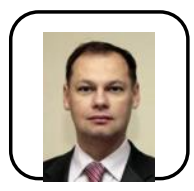

Maksim Rebezov doctor of agricultural sciences, professor, K.G. Razumovsky Moscow State University of technologies and Management (the First Cossack University)»; Ural State Agrarian University; V.M. Gorbatov Federal Research Center for Food Systems of the Russian Academy of Sciences.

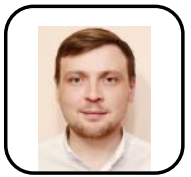

Mars Khayrullin candidate of technical sciences, associate professor, K.G. Razumovsky Moscow State University of technologies and management (the First Cossack University). 